\title{
Analisis Kedudukan Waktu dalam Keabsahan Praktek Jual Beli Syariah
}

\author{
Rahmat Hidayat \\ rahmathidayat@uinsu.ac.id \\ Universitas Islam Negeri Sumatera Utara
}

\begin{abstract}
This article aims to analyze the position of time and its correlation with sharia sale and purchase transactions, to answer time problems in each component of buying and selling transactions. Buying and selling is a transaction that is most often carried out by humans in meeting their daily needs. One of the main components of buying and selling that distinguishes it from other transactions is the transfer of ownership by handing over the goods with the value of the goods. Normally, the handover of goods occurs in a sale and purchase activity known as the majlis aqd. However, due to certain factors, the handover may experience delays. A delay or suspension which is a derivative of time has a certain effect on the validity of a sale and purchase contract. So that it can be understood that global universal time has a special position in buying and selling. This research uses content analysis method by making classic and contemporary scholarship books as references plus several journals. This study deduced the opinions of scholars regarding payment or delivery of delayed items which were then analyzed by the authors to be a conclusion. The results of this study indicate that the conditions of time can determine whether or not the sale and purchase agreement is valid. In addition to several aspects, the aspect of clarity of time is very important to note.
\end{abstract}

Keywords : Buy and sell, Validity of buying and selling, Time delay

\begin{abstract}
Abstrak
Penelitian ini bertujuan untuk menganalisis kedudukan waktu dan korelasinya dengan transaksi jual beli syariah, untuk menjawab problematika waktu di setiap komponen transaksi jual beli. Jual beli merupakan transaksi yang paling sering dilakoni manusia dalam memenuhi kebutuhan hidupnya sehari-hari. Salah satu komponen utama jual beli yang membedakannya dari transaksi lain adalah adanya perpindahan kepemilikan dengan serah terima barang dengan uang senilai barang tersebut. Normalnya, serah terima barang terjadi dalam satu aktifitas transaksi jual beli yang dikenal dengan majlis aqd. Tetapi, karena adanya faktor-faktor tertentu, serah terima dapat mengalami penundaan. Penundaan atau penangguhan yang merupakan turunan dari waktu
\end{abstract}

Al-Istinbath : Jurnal Hukum Islam Vol. 4, No. 1, 2019; 125-142

p-issn: 2548-3374; e-issn: 2548-3382; DOI: 10.29240/jhi.v4i1.795

Available online at: http://journal.staincurup.ac.id/index.php/alistinbath 
memiliki efek tertentu terhadap keabsahan suatu akad jual beli. Sehingga dapat dipahami bahwa waktu yang bersifat global universal memiliki kedudukan khusus dalam jual beli. Penelitian ini mengunakan metode content analysis dengan menjadikan buku-buku ulama klasik dan kontemporer sebagai rujukan ditambah dengan beberapa tulisan ilmiah. Penelitian ini mendeduksi pendapat ulama terkait pembayaran atau penyerahan barang tertunda yang kemudian dianalisa oleh penulis menjadi gugus kesimpulan. Hasil penelitian ini menunjukkan bahwa kondisi waktu dapat menentukan sah tidaknya akad jual beli. Selain beberapa aspek, aspek kejelasan waktu sangat penting untuk diperhatikan.

Kata Kunci : Jual-beli , Keabsahan jual beli, Penundaan waktu

\section{Pendahuluan}

Ekonomi secara substansial merupakan salah satu unsur krusial keberlangsungan kehidupan manusia. Setiap manusia pasti terkait dengan kegiatan ekonomi, baik sebagai pelaku utama maupun sebatas ruang konsumsi. Keharusan manusia untuk memenuhi kebutuhannya yang sebahagian besar hanya dapat terpenuhi dengan transaksi ekonomi tidak terlepas dari karakter manusia sebagai makhluk sosial yang tidak bisa memenuhi segala kebutuhannya secara mandiri. Manusia membutuhkan kerjasama dan bantuan dari yang lainnya untuk memastikan keberlangsungan hidupnya berjalan dengan baik.

Jual beli yang dikenal dengan istilah bai' dalam Bahasa Arab merupakan salah satu jenis transaksi ekonomi. Jual beli yang beresensikan pertukaran barang dengan alat tukar ${ }^{1}$ terus mengalami perkembangan, baik secara sistem serah terima barang, sistem pembayaran maupun sistem pemesanan. Paparan digitalisasi sebagai imbas dari perkembangan teknologi sangat mempengaruhi perubahan ini. Sistem fintech $^{2}$ yang makin digalakkan mempengaruhi persepsi dan pola fikir pelaku usaha dan sistem usaha itu sendiri. Sistem jual beli dalam jejaring, unicorn site, COD (cash on delivery), e-money, prepaid card, cashback, dan sistem financial technology lainnya terus muncul seiring dengan glamouritas di era industri 4.0 .

Jual beli dalam lingkup yuridis Islam, memiliki tiga rukun utama. Pertama, penjual dan pembeli. Kedua, barang yang diperjual-belikan. Ketiga,

${ }^{1}$ Alat tukar harus bersifat dapat diterima secara umum sebagai alat pembayaran seperti uang kartal, giral, kuasi atau item lainnya seperti emas dan perak.

${ }^{2}$ Definisi fintech seperti yang dijabarkan oleh National Digital Research Centre (NDRC) adalah istilah yang digunakan untuk menyebut suatu inovasi di bidang jasa financial yang mengacu pada inovasi financial dengan sentuhan teknologi modern. Fintech merupakan salah satu bentuk penerapan teknologi informasi dibidang keuangan dengan muncul berbagai model keuangan baru dimulai pertama kali pada tahun 2004 oleh Zopa, yaitu institusi keuangan yang berada di Inggris yang menjalankan jasa peminjaman uang. Lihat: Ridwan Muchlis. Analisis SWOT Financial Technology (Fintech) Pembiayaan Perbankan Syariab Di Indonesia; Studi Kasus 4 Bank Syariah Di Kota Medan. At-Tawassuth, Vol. III, No. 2, 2018, hlm. 343. 
sigat atau ijab kabul. ${ }^{3}$ Secara explisit, tidak ada penyebutan pembayaran dan penyerahan barang dalam rukun jual beli. Penyerahan barang dan pembayaran akan kita temui dalam syarat-syarat jual beli yang sering diistilahkan dengan qabdu al-saman atau qabdual-mabi'.

Pembayaran maupun penyerahan barang yang sejatinya terjadi di dalam satu majlis 'aqd (tempat transaksi) nyatanya mempunyai bentuk lain, baik dari pembayaran yang ditangguhkan ataupun penyerahan barangnya. Waktu sebagai suatu kesatuan yang bersifat universal memiliki pengaruh atau hubungan terhadap segala model aktifitas, tak terkecuali jual beli. Durasi dan tempo waktu mempunyai keterkaitan dengan jual beli dalam konteks mewujudkan kemudahan bertransaksi. Kondisi ketiadaan barang yang diinginkan, keuangan yang tidak mencukupi, perencanaan ke depan, posisi penjual dan pembeli yang jauh, merupakan beberapa alasan tertundanya pembayaran ataupun penyerahan barang.

Permasalahan yang muncul pada masyarakat pada saat ini adalah fenomena kehati-hatian dalam setiap transaksi, bahkan cenderung mengharamkan. Kecenderungan masyarakat saat ini menganggap bahwa pertambahan nilai atas harga suatu benda karena adanya durasi waktu adalah riba. Secara literal, riba adalah bertambah, tumbuh dan berkembang, akan tetapi tidak semua yang bertambah dan berkembang adalah riba. Waktu yang bersifat universal tidak mungkin dipisahkan dari transaksi ekonomi yang ada, termasuk jual beli. Jual beli seperti dengan sistem kredit, pesanan atau dengan total down payment (TDP) bahkan flash commerce yang substansinya adalah adanya durasi waktu di luar majlis akad, bagi beberapa kalangan justru dihukumi dengan haram secara general. Konsepsi yang tidak tepat ketika generalisir digunakan dalam menghukumi perilaku muamalah.

Merujuk tulisan ilmiah terdahulu, beberapa tulisan memaparkan permasalahan waktu dalam jual beli dalam satu arah, baik hanya dalam penundaan pembayaran maupun dalam penyerahan barang. Adanan Murroh Nasution dalam tulisannya yang berjudul jual beli kredit ditinjau dari perspektif hukum Islam membahas esensi transaksi dengan penundaan pembayaran secara umum. Pembahasan lebih dititikberatkan kepada keabsahaan akad dalam perspektif syariah. ${ }^{4}$ Analisis waktu yang muncul dalam tulisan tersebut hanya sebatas data penunjang sistematika pembahasan. Tulisan ilmiah terkait dengan penundaan dalam transaksi jual beli juga dapat dilihat dari tulisan jurnal yang berjudul 'Akad Salam Dalam Transaksi Jual Beli' yang memaparkan pemesanan barang dengan pembayaran di awal. Tulisan ini membahas akad dengan aturan

\footnotetext{
${ }^{3}$ Abu Zakaria An-Nawawi. Al-Majmu' Syarh Al-Mubazzab. Juz 9. Cet. 1. Beirut: Dar AlFikr, 1996, hlm. 149.

${ }^{4}$ Adanan Murroh Nasution. Jual Beli Kredit Ditinjau Dari Persefektif Hukum Islam. Yurisprudentia. Vol. 2 No. 2 Desember 2016. hlm. 19.
} 
spesifikasi dan harga barang pesanan harus sudah disepakati di awal akad, sedangkan pembayaran dilakukan di muka secara penuh. ${ }^{5}$ Korelasi waktu yang muncul di tulisan ini sebatas data sekunder dan bukan premier. Waktu juga dapat mempengaruhi tingkat penjualan suatu produk. H. Hasbudin Wa Ode Nur Hidayah dalam tulisannya di jurnal UHO memberikan kesimpulan bahwa dari hasil penelitian ditemukan variabel uang muka (penundaan pembayaran secara penuh) mempunyai pengaruh positif dan signifikan terhadap volume penjualan, variabel lama angsuran mempunyai pengaruh negatif tidak signifikan terhadap volume penjualan. Secara simultan uang muka dan lama angsuran mempunyai pengaruh yang signifikan terhadap volume penjualan karena kedua variabel ini merupakan faktor yang diperhatikan konsumen dalam setiap penjualan angsuran. ${ }^{6}$

Melihat waktu yang memiliki pengaruh terhadap legalitas jual beli, maka perlu analisis terhadap korelasi waktu dengan aktifitas jual beli. Penulis menggunakan metode content analysis dengan merujuk kepada buku-buku yang memaparkan dimensi waktu dalam jual beli. Pendekatan masalah yang digunakan dalam tulisan ini adalah pendekatan kualitatif. Dimulai dengan memberikan batasan yang jelas tentang jual beli, baik dalam pengertian dan legalitas, dan pembagian jual beli berdasarkan waktu, penulis akan memulai analisis terhadap waktu. Hal ini tidak terlepas dari kedudukan waktu, baik dari sisi durasi, sifat dan kejelasannya dapat mempengaruhi keabsahaan sebuah transaksi. Penekanan analisis waktu lebih kepada waktu pembayaran dan penyerahan barang yang merupakan esensi dari transaksi jual beli. Analisa ini diharapkan dapat memberikan visibilitas yang tepat terkait waktu dan jual beli.

\section{Pembahasan}

\section{Pengertian dan Legalitas Yuridiksi Jual Beli}

Menilik dari etimologi, jual beli dalam bahasa arab disebut juga dengan bai' yang berarti menerima sesuatu dengan memberikan sesuatu yang lain. ${ }^{7}$ Kata $b a ' i$ merupakan derivasi dari kata kerja $b a^{\prime} a^{8}{ }^{8}$ Secara terminologi, terdapat variasi definisi yang dikemukan oleh fuqaha atas arti dari kata bai', antara lain sebagai berikut:

${ }^{5}$ Saprida. Akad Salam dalam Transaksi Jual Beli. Mizan. Vol.4 No.1. 2016. hlm. 121.

${ }^{6}$ H. Hasbudin Wa Ode Nur Hidayah. Pengarub Uang Muka dan lama Angsuran Terbadap Volume Penjualan Motor Yamaba Pada CV. Citra Selaras Raba. UHO: Jurnal Akuntansi dan Keuangan Fakultas Ekonomi Dan Bisnis. Vol. 1, No. 1, 2016. hlm. 12.

${ }^{7}$ Muhammad bin Makram bin Mandzur. Lisan Al-'Arab. Juz 8. Cet. 4. Beirut: Dar AlSadir, 1414H, hlm. 23.

${ }^{8}$ Ibnu Mandzur, Lisan Al-'Arab (Beirut: Dar Al-Sadir, 1414), Juz 8, hlm. 23. 
a. Menurut Mazhab Hanafi, jual beli adalah transaksi harta dengan harta disertai dengan kerelaan pihak yang bertransaksi. ${ }^{9}$

b. Menurut Mazhab Maliki, jual beli berarti akad mu'a>wad\}ah (saling bertukar) di luar konteks manfaat (sewa) dan di luar konteks mendapatkan pelayanan (jasa). ${ }^{10}$

c. Menurut Mazhab Syafi'i, jual beli adalah pertukaran harta dengan harta dengan ketentuan khusus. ${ }^{11}$

d. Menurut Mazhab Hanbali, jual beli adalah pertukaran harta dengan harta yang menyebabkan (pertukaran) kepemilikan.

Dari keempat terminologi di atas, maka dapat disimpulkan beberapa hal terkait akad jual beli, di antaranya:

1. Akad yang mengikat pihak-pihak yang bertransaksi, dimana pihak yang pertama menyerahkan barang dan pihak kedua membayar nilai barang tersebut.

2. Pertukaran terjadi atas benda atau sesuatu yang memiliki nilai dengan alat tukar (uang).

3. Akad terjadi dengan landasan kerelaan dari pihak yang bertransaksi

4. Adanya perpindahan kepemilikan atas benda atau barang berharga.

Analisis ini memberikan gambaran bahwa jual beli menuntut adanya perpindahan harta antara pihak-pihak yang terkait. Pada dasarnya, sifat dari jual beli adalah adanya perpindahan barang secara tunai di tempat transaksi (majlis 'aqd). Bahkan, di beberapa jenis barang, serah terima atau qabdu merupakan salah sah transaksi seperti mana dalam jenis benda-benda ribawi. ${ }^{12}$ Oleh karena itu, adanya penundaan pembayaran maupun penyerahan benda ketika transaksi menjadi hal perlu dianalisa, baik dalam legalitasnya maupun hal-hal yang perlu dihindari.

Idealnya, jual beli merupakan serah terima barang dengan uang maupun alat pembayaran di tempat terjadinya transaksi (majlis). Salah satu kaidah fikih dalam muamalah secara explisit menyebutkan bahwa jual beli atas benda yang tidak ada ketika transaksi (bai' ma'dum) adalah terlarang. Pada intinya, aturan ini muncul untuk menghindari ketidakjelasan, kecurangan, dan penipuan salah satu pihak terhadap pihak yang lain yang dapat menyebabkan kerugian material yang berdampak pada munculnya konflik antara para penikmat transaksi jual beli.

${ }^{9}$ Zainuddin bin Nujaim Al-Mashry Al-Hanafi Al-Babr Al-Ra iq Syarb Kanz. Al-Daqa iq. Juz 5. Cet.2. (Kairo: Dar Al-Kitab Al-'Islamy, tt), hlm. 277.

${ }^{10}$ Muhammad bin Ahmad Al-Dasuqi. Hasyiyah Al-Dasqi Ala Syarb Al-Kabir, Juz. 3. Beirut: Dar Al-Fikr, tt, hlm. 2.

11 Abu Bakar Al-Dimyathi. 'T'anah Al-Talibin, Juz 3. Cet. 1. (Beirut: Dar Al-Fikr, 1997M), hlm. 6 .

12 Taqiyuddin Al-Dimasyqi. Kifayah Al-Akbyar fi Halli Gayah Al-Tkbtisar. Cet. 1. (Kairo: Dar Al-Salam, 2007M), hlm. 314. 
Di sisi lain, perlu juga dipahami bahwa Islamic legal maxim yang paling utama dalam ruang lingkup muamalah adalah hukum asal kebolehan segala transaksi muamalah selama tidak adanya dasar yang melarang kegiatan tersebut. Logikanya adalah, bahwa muamalah merupakan konsep buman connecting, konsep yang terkait erat dengan persaingan dan pengembangan sehingga ruang ini harus dibebaskan untuk berinovasi dan bereksperimen dengan dinamikanya sehingga muncullah ide-ide kreatif dan inovatif, baik dari sistem transaksi maupun dari objeknya.

Dalam hukum syara', seperti mana yang diungkapkan oleh Imam Syiahabuddin Al-Janzany bahwa jual beli termasuk dalam aktifitas mubah dan ini telah disepakati ulama. ${ }^{13}$ Secara global, jual beli dengan berbagai modelnya boleh untuk dilakukan selama tidak melanggar batasan-batasan yang telah ditetapkan. Paling tidak ada beberapa hal yang harus diperhatikan dalam suatu transaksi jual beli menurut Islam.

1. Harus bersifat jelas dan diketahui. Barang yang diperjualbelikan dan harga barang tersebut dan hal-hal yang terkait harus jelas dan diketahui kedua belah pihak. Ketidakjelasan dapat menyebabkan rusaknya akad. ${ }^{14}$ Seperti mana hadis Rasulullah SAW.: "Sesungguhnya Nabi melarang akad garar (ketidakpastian)." 15

2. Tidak adanya paksaan. Paksaan secara umum bisa membatalkan apapun termasuk di dalamnya jual beli. Hal ini sesuai dengan hadis Rasulullah SAW.: "Sesungguhnya jual beli itu saling ridha.,"16

3. Tidak adanya kecurangan dan kebohongan. Hal ini lumrah diketahui bahwa kecurangan dan kebohongan adalah hal yang terlarang dalam segala aktifitas.

4. Tidak berbahaya dan tidak membahayakan. Jual beli, baik dari sisi barang, cara bertransaksi maupun sisi lainnya harus terlepas dari sifat bahaya dan membahayakan, seperti mana hadis Rasulullah saw: "Tidak berbahaya dan tidak boleh membahayakan." ${ }^{17}$

5. Tidak adanya syarat yang bisa membatalkan jual beli, seperti syarat barang harus dijual kembali kepada penjual setelah setahun.

6. Barang yang dijual harus barang yang baik, bukan barang diharamkan, baik secara objek barang atau cara mendapatkannya.

\footnotetext{
${ }^{13}$ Syiahabuddin Al-Janzany, Takbrij Al-Furu' 'Ala Al-Usul. Cet. 2. (Beirut: Muassasah Al-Risalah, 1398H), hlm. 157.

${ }^{14}$ Muhammad Syamsuddin Asy-Syarbaini. Al- 'IqnäfilHalli Alfazi Abi Syuja'. Juz 2. Cet. 3. (Beirut: Dar Al-Kutub Al-'Ilmiyah, 2004), hlm. 80.

15 Imam Ahmad bin Hanbal. Musnad Imam Ahmad bin Hanbal. Juz 12. Cet. 1. (Beirut: Muassasah Al-Risalah, 2001M), hlm. 373.

16 Muhammad Ibnu Hibban. Sabib Ibn Hibban. Juz 11. Cet. 2. (Beirut: Muassasah AlRisalah, 1993M), hlm. 340.

${ }^{17}$ Malik bin Anas bin Malik. Munatta' Imam Malik. Juz 2. (Beirut: Muassasah Al-Risalah, 1412H), hlm. 467.
} 
7. Larangan menawar barang yang sedang ditawar oleh orang lain yaitu ketika suatu barang yang talah disepakati harganya antara penjual dan pembeli yang pertama tiba-tiba datang pembeli yang kedua menawar dengan harga yang lebih mahal, lalu penyerahan barang diberikan kepada pembeli yang kedua. ${ }^{18}$

Hal-hal di atas merupakan aturan universal dalam akad jual beli, bahkan diterapkan juga terhadap akad-akad syariah yang lainnya.

\section{Jual Beli Dilihat Secara Waktu}

Waktu tidak termasuk dalam rukun jual beli. Tapi waktu mempunyai pengaruhi besar terhadap keabsahan suatu transaksi, termasuk di dalamnya jual beli. Salah satu bagian dari waktu yang memiliki keterikatan kuat dengan jual beli adalah penundaan. Ulama mengistilahkannya ini dengan term ta jil. Kata ini merupakan derivasi dari kata ajjala yu ajjilu yang kata aslinya adalah ajala dengan awalan hamzah dan bukan dengan 'ain. 'Ajal secara bahasa dapat diartikan dengan durasi objek. Durasi disini berarti waktu antara akad dengan penyerahan di masa datang yang telah ditentukan, yang telah disepakati oleh kedua belah pihak. Durasi ini secara hukum mengikat kedua bela pihak. Tidak melaksanakan kewajiban terkait kesepakatan atas durasi waktu tanpa alasan syar'i merupakan suatu tindakan pengkhianatan dan tidak dibenarkan dalam prinsip muamalah Islam yang berlandaskan sikap amanah dan jujur.Ditilik berdasarkan waktu, jual beli dibagi menjadi dua bagian, jual beli tunai dan jual beli tertunda.

Jual beli tunai ataupun mutlak yaitu jual beli yang pembayaran dan serah terima barang dilakukan di tempat terjadinya transaksi antara penjual dan pembeli atau majlis 'aqd. Jual beli model ini dianggap sebagai jual beli yang paling baik bila ditilik dari waktu. Penyerahan barang dan alat tukar yang dilakukan dalam satu waktu transaksi dianggap mampu meminimalisir tindakan penipuan, kecurangan, ketidakjelasan dan hal-hal lain yang dapat membatalkan transaksi syariah. Pembeli dalam model akad ini memiliki hak antara membayar barang tersebut ataupun membatalkan transaksi bila dia mendapati barang yang akan dibelinya tidak sesuai keinginannya. ${ }^{19}$ Dalam jual beli mutlak atau tunai ini, hal terkait waktu yang harus diperhatikan yaitu pembayaran dan penyerahan barang terjadi dalam satu waktu transaksi tanpa adanya penundaan.

Sedangkan jual beli tertunda memiliki beberapa jenis dan model. Pertama, Bai' Mu ajjal Al-Saman atau jual beli dengan penundaan pembayaran. Kedua, Bai' Mi aijal Al-Musamman atau jual beli dengan penundaan penyerahan barang. Ketiga, Bai' Mu ajjal 'Audain atau jual beli dengan penundaan pembayaran dan penyerahan barang secara bersamaan yang dikenal juga dengan jual beli hutang dengan hutang.

${ }^{18}$ Syaifullah M.S. Etika Jual Beli Dalam Islam. Hunafa: Jurnal Studia Islamika. Vol. 11, No. 2, Desember 2014. hlm. 385.

${ }^{19}$ Al-Dimasyqi. Kifayah Al-Akhyar. hlm. 321. 
Ketiga jenis bai' mu ajjal ini memiliki karakteristik yang berbeda sehingga perlu penjelasan khusus agar dapat memberikan gambaran yang menyeluruh terkait hubungannya dengan waktu.

\section{Bai' Mu 'ajjal Al-Saman (Bai' Nasi'ah)}

Jual beli dengan pembayaran tertunda sedangkan barang telah diterima terlebih dahulu ketika akad adalah hal yang lumrah dalam transaksi sehari-hari. Faktor kebutuhan penjual dan pembeli menjadikan model transaksi ini menjadi solusi untuk beberapa kendala. Pembayaran tertunda juga memiliki beberapa jenis. Pertama, pembayaran tertunda kontan atau pelunasan dilakukan dalam satu transaksi pembayaran. Kedua, pembayaran tertunda kredit. Ketiga, pembayaran tertunda dengan sistem down payment.

Secara global, jenis pertama dan kedua,yang juga dikenal dengan istilah bai' nasi ah, boleh untuk diaplikasikan dalam transaksi jual beli, selama tidak bertentangan dengan aturan-aturan umum muamalah, seperti riba, ketidakpastian, kecurangan, paksaan dan lain-lain.

Keterkaitan dua jenis bai' nasi ah ini dengan waktu dapat ditilik dari beberapa aspek. Aspek-aspek ini terkait dengan penyerahan barang, pembayaran, sifat dan pengaruhnya terhadap transaksi. Analisis terhadap aspekaspek ini menghasilkan beberapa kesimpulan, yaitu:

1. Waktu penyerahan barang.

Fuqaha' sepakat bahwa dua jenis bai' mi aijal ini menuntut penyerahan barang di awal akad sebagai syarat mutlak dari keabsahan akad jenis ini. Penyerahan barang dan pembayaran yang tertunda akan menyebabkan akad menjadi akad iwadain atau ada hutang dengan hutang. Akad iwadain sendiri dihukumi haram oleh mayoritas ulama fikih.

2. Waktu pembayaran.

Secara esensi dan penamaan, jual beli ini terfokus pada adanya persyaratan penundaan pembayaran yang bersifat mengikat pembeli. Penamaan bai' miajjal saman muncul sebagai term dari adanya penundaan pembayaran. Jika waktu pembayaran dilaksanakan di dalam majlis akad bersamaan dengan penyerahan barang maka akad tersebut berbentuk jual beli tunai. Dan bila dalam jual beli tunai terdapat persyaratan penundaan pembayaran maka persyaratan itu batal dan akad tetap sah.

3. Penetapan waktu atau durasi pembayaran.

Tempo atau durasi waktu pelunasan harus ditetapkan, dijelaskan dan dirincikan ketika akad.Persyaratan kejelasan waktu pembayaran mutlak harus disepakati di waktu penyerahan barang. Syarat ini mengikat dan wajib dipatuhi oleh pembeli. 'Ajal Majbul atau ketidakjelasandurasi batas pembayaran menyebabkan akad ini menjadi rusak. 
4. Sifat waktu pembayaran.

Waktu pembayaran bersifat mengikat bagi pembeli. Pembeli wajib mematuhi kesepakatan terkait waktu pembayaran. Bila pembeli enggan membayar padahal dia mampu maka penjual berhak menuntut keadilan dengan menggunakan aturan hukum dan perundang-undangan yang berlaku di tetorialnya.

5. Pengaruh penundaan pembayaran terhadap harga.

Penjual boleh mempertimbangkan penambahan harga di awal akad di karenakan adanya penundaan waktu pembayaran.Tempo singkat antara waktu akad dan pelunasan mungkin tidak memberikan efek domino bagi penjual. Karena dalam durasi waktu yang singkat, kemungkinan terjadinya perubahan harga sangat minim dan juga kebutuhan penjual akan modal tidak terlalu terasa. Berbeda halnya jika tempo pelunasan menyita waktu yang panjang, kemungkinan inflasi, kenaikan harga jual barang, ataupun kebutuhan akan modal usaha memberikan dampak yang signifikan bagi penjual.Oleh karena itu, penjual boleh menaikkan harga barang di awal akad dan harga haruslah bersifat flat dan tidak boleh berubah setelah terjadinya akad.

6. Waktu tidak boleh menjadi alasan perubahan harga di saat pelunasan.

Perubahan harga di tengah atau ketika jatuh tempo pembayaran dari harga yang ditetapkan di awal akad termasuk dalam perbuatan riba. Setelah adanya kesepakatan harga di awal maka tidak boleh ada perubahan baik karena pertimbangan panjangnya durasi yang disepakati ataupun karena adanya penambahan waktu disebabkan ketidaksanggupan pembeli melunasi ketika jatuh tempo. Seperti mana dijelaskan sebelumnya, penjual boleh menaikkan harga ketika akad dengan pertimbangan tempo pembayaran yang panjang tetapi tidak boleh merubahnya setelah terjadinya kesepakatan.

Bila dalam tempo yang ditetapkan pembeli belum mampu melunasi dengan bukti-bukti yang kuat maka penjual boleh menambah durasi pelunasan, seperti mana sabda Rasulullah Saw :

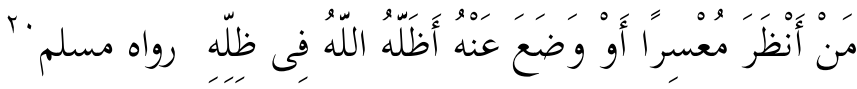

"Barangsiapa memberikan durasi tambahan bagi orang yang berada dalamkesulitan dalam melunasi butang atau babkan membebaskan utangnya, maka Allab menaunginya dalam naunganNya." (HR. Muslim).

Dari model bai' saman mu ajjal di atas, muncul permasalahan yang sering terjadi di masyarakat. Dalam memenuhi kebutuhan hidup harian, seseorang sering membeli sesuatu ke toko atau ke penjual kebutuhan harian di dekat rumahnya dan kemudian mengatakan: "nanti akan saya bayar". Kata nanti ditilik

${ }^{20}$ Muslim bin Hajjaj Al-Nisabury. Sahih Muslim. Juz 4. (Beirut: Dar `Ihya`Al-Turas Al'Araby, tt), hlm. 2301. 
dari bahasa tidak termasuk 'ajal ma'lum atau waktu yang jelas karena kata nanti berarti waktu di masa yang akan datang tanpa ada batasan. Walaupun dalam KBBI online, katananti adalah waktu yang tidak lama dari sekarang. ${ }^{21}$ tetapi tetap saja tidak ada batasan yang jelas.Permasalahan ini bisa terjadi karena kebutuhan yang mendesak disertai ketiadaan finasial pada saat itu dan barang yang dibeli relatif murah, atau bisa juga perkataan nanti hanya sebatas perkataan atau basabasi karena pembeli masih berada di majlis akad dan belum ada keinginan untuk beranjak. Masyarakat pada umumnya melihat ini sebagai hal yang lumrah dan sudah menjadi kebiasaan sehingga munculnya anggapan bahwa jual beli model ini diperbolehkan. Alasan lainnya adalah adanya hubungan kedekatan maupun kekerabatan antara penjual dan pembeli.

Imam Ibnu Abidin dalam kitab Radd Al-Mukbtar 'Ala Al-Darri AlMukbtar,menjelaskan bahwa ketika ada jual beli yang di dalamnya terjadi penundaan pembayaran, seperti pembayaran berangsur setiap minggu, tetapi penundaan itu tidak disebutkan sebagai syarat akad jual beli tetapi hanya diutarakan setelahnya maka akad tersebut tetap sah. ${ }^{22}$ Jual beli ini juga dapat dianggap sah bila ditilik dari pendapat ulama seperti Shan'anydalam Subulussalam yang membolehkan jual beli muyassarah (jual beli yang pembayarannya dilakukan ketika pembeli sudah memiliki dana).

Penulis sendiri melihat bahwa hal ini sebaiknya dihindari, walaupun pembeli tetap melunasinya di kemudian hari. Sesuatu yang terhutang walaupun secara kebiasaan dibayar dalam tempo singkat sebaiknya tetap diikat dengan waktu dan dicatat secara khusus agar tidak menimbulkan konflik di kemudian hari. Wallahu a'lam.

Jenis lain dari pembayaran tertunda adalah jual beli menggunakan down payment atau dalam Syariah dikenal juga dengan 'urbun. Jenis ini dipisahkan dari dua jenis bai' mu'ajjal al-samansebelumnya karena ada silang pendapat ulama terkait keabsahan akad ini. Silang pendapat ini bermuara dari kedudukan uang muka yang hangus bila si pembeli tidak jadi membeli barang tersebut. Ulama Hanafiyah, Malikiyah dan Syafi'iyah menolak transaksi ini dengan beberapa argumentasi, di antaranya:

1. Hadis yang diriwayatkan Imam Malik bahwasannya Nabi melarang transaksi urbun. ${ }^{23}$

2. Ada dua syarat tertolak dalam transaksi ini, yaitu penjual menerima uang muka yang telah dibayarkan bila pembeli membatalkan transaksi atau

${ }^{21}$ https://kbbi.web.id/nanti, diakses 9 Februari 2019

${ }^{22}$ Muhammad Amin Ibnu Abidin. Radd Al-Mukbtar 'Ala Al-Darri Al-Mukbtar. Juz 4. Cet. 2. (Beirut: Dar Al-Fikr, 1992M), hlm. 531.

${ }^{23}$ Malik bin Anas bin Malik. Muwat $\} t\left\{a^{`}\right.$ Imam Malik. Juz 4. Cet. 1. (Abu Dhabi: Muassasah Zayid bin Sultan, 2004M), hlm. 879. 
pembeli dapat mengembalikan barang yang telah dibelinya sebelum pelunasan. ${ }^{24}$

3. Transaksi ini termasuk ke dalam tindakan memakan harta orang lain secara batil. Karena pembeli dapat kehilangan uangnya tanpa mendapatkan benda atau pengganti yang sepadan dengan uang yang telah diserahkannya kepada penjual.

Beberapa ulama lain seperti Ulama Hanbali, Syeikh bin Baz dan fatwa Lajnah Daimah no 13/133 memberikan legalitas transaksi ini ditilik dari beberapa hal, di antaranya:

1. Hadis yang diriwayatkan oleh Zaid bin Aslam bahwa Rasulullah ditanya tentang jual beli 'urbun dan beliau menghalalkannya. ${ }^{25}$

2. Kejadian di masa umar dimana salah satu stafnya membeli rumah sofyan bin umayyah di Mekkah untuk dijadikan penjara dengan down payment sebesar 4000 dirham. Bila umar memutuskan untuk membeli rumah maka uang muka itu termasuk dalam pembayaran, dan kalau umar menolak maka uang tersebut menjadi milik penjual. ${ }^{26}$

3. Uang down payment dianalogikan sebagai uang penjamin untuk waktu tunggu. Dalam waktu tunggu pembeli untuk melunasi keseluruhan harga, penjual tidak dirugikan menahan barang karena ada nilai yang dibayarkan untuk itu.

Penulis cenderung kepada pendapat kedua yang menyatakan kebolehan bai' 'urbun karena pembeli memberikan uang muka agar penjual tidak menjual barang itu kepada pihak lain dalam batas waktu tertentu. Hak khiyar pembeli dan kewajiban penjual untuk menjaga barang menjadi tanggungan bagi penjual. Maka uang muka itu dapat dianggap sebagai kosekuensi dari tanggungan yang dibebankan kepada penjual.

Bila jual beli dengan down payment dianggap sah, maka muncul kosekuensi terkhusus dalam kaitannya dengan waktu, yaitu:

1. Kejelasan waktu down payment

Kejelasan waktu adalah adanya durasi waktu yang ditentukan antara pembayaran down payment dengan keputusan pembeli untuk mengambil barang tersebut atau menolaknya. Ini dimaksud untuk menghindari ketidakpastian bagi penjual.

${ }^{24}$ Muhammad bin Ali bin Muhammad Al-Syaukani. Nail Al-Autar min `Ahadisi Sayyid Al- Akbyar, Juz 5. (Beirut: Dar Jail, 1973M), hlm. 251.

${ }^{25}$ Al-Husein bin Muhammad Al-Maghriby. Al-Badr Al-Tamam Syarb Bulug Al-Muram. Juz 6. Cet. 1. (Kairo: Dar Hajar, 2007M), hlm. 78.

${ }^{26} \mathrm{Abu}$ Abdullah Al-Fakihi. 'Akbar Al-Makkah fi Qadim Al-Dabri wa Hadisih. Juz 3. Cet. 2. (Beirut: Dar Khadar, 1414 H), hlm. 233. 
2. Adanya penetapa durasi waktu untuk pelunasan jika pembeli memutuskan untuk mengambil barang tersebut seperti mana di bai' mu'ajjal al-saman yang lainnya.

3. Penetapan harga terjadi ketika pembayaran down payment, bukan ketika pembeli akan memutuskan untuk melanjutkan akad atau membatalkannya.

Poin ini penting untuk diperhatikan agar tidak terjadi kecurangan dari penjual dengan menaikkan harga dalam masa durasi tunggu keputusan penjual. Karena penjual bisa saja dengan sengaja menaikkan harga agar pembeli membatalkan pembelian sehingga dia mendapatkan down payment, atau dia mendapatkan keuntungan tambahan jika pembeli tetap mengambil barang tersebut.

\section{Bai’ Mu ajjal Musamman}

Jual beli dengan penyerahan dana di awal dan penyerahan barang di kemudian hari termasuk dalam transaksi yang sering dijumpai. Akad ini biasanya sebagai bentuk dari ketiadaan barang ketika akad atau adanya keinginan khusus dari pembeli yang tidak dapat dipenuhi ketika akad berlangsung. Jual beli ini merupakan kebalikan jual beli pembayaran tertunda.

Jual beli seperti ini dikenal juga dengan bai' salam. Pendapat yang lain juga memasukkan akad istisna' ke dalam jenis ini. Tetapi penulis melihat bahwa akad istisna' tidak masuk ke dalam bai' mu ajjal musamman karena beberapa hal. Pertama, akad istisna' adalah akad yang tidak mengikat antara penjual dan pembeli. Kedua, tidak adanya ikatan waktu terkait durasi bagisani' (pembuat barang) harus menyerahkan barang. Ketiga, akad ini juga dapat dilakukan dengan akad ijarah (jasa) dimana mustasni' (yang meminta pembuatan) menyediakan semua keperluan dan sani' hanya mengeluarkan skill atau jasanya saja. Kalau memang akad istisna' mengikat maka akad ini juga dapat dimasukkan ke dalam jenis akad salam.

Salam secara etimologi berarti salaf atau terdahulu dan lampau. Kata salam digunakan oleh mayoritas penduduk Madinah sedangkan kata salaf digunakan oleh mayoritas penduduk Irak. Jual beli ini telah dipraktekkan oleh masyarakat pra Islam, tetapi mereka tidak menjelaskan ukuran, berat, sifat, dan waktu penyerahan sehingga sering terjadi kecurangan dalam akad ini.

Pengertian salam secara istilah adalah jual beli dengan spesifikasi tertentu dalam tanggungan dan penyerahan barang tertunda dengan pembayaran di serahkan waktu akad majlis. ${ }^{27}$ Berdasarkan terminologi ini maka dapat dipahami bahwa salam berarti penyerahan pembayaran di awal dan penyerahan barang yang telah ditentukan spesifikasinya dilakukan di waktu yang akan datang yang

${ }^{27}$ Panji Adam. Fikih Muamalah Maliyah. Cet. 1. (Bandung: Refika Aditama, 2017M), hlm. 62. 
telah disepakati. Kata zimah yang sering digunakan dalam terminologi salam menunjukkan bahwa muslam 'alaihi (penjual) bertanggung jawab atas muslam fih (barang yang dijual).

Secara hukum, ulama berkonsensus atas keabsahaan akad salam. Hal ini didasari pada beberapa hadis Rasulullah Saw. Rasulullah Saw bersabda:

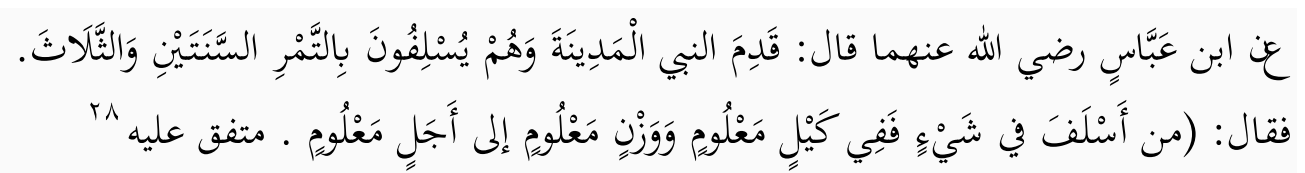

"Dari sahabat Ibnu Abbas radbiallabu 'anbuma, ia berkata: "Ketika Nabi tiba di kota Madinah, dan mereka (penduduk. Madinah) memesan buah kurma dalam durasi waktu dua tahun dan tiga tahun, maka beliau bersabda: "Barang siapa yang memesan sesuatu, maka hendaknya ia memesan dalam jumlah takaran yang telah diketahui (oleh kedua belah pibak), dan dalam timbangan yang telah diketabui (oleh kedua belah pibak), dan bingga batas waktu yang telah diketabui (oleh kedua belah pihake) pula." (Muttafaq 'alaib)

Dari hadis ini dapat dilihat bahwa waktu mempengaruhi keabsahaan akad salam. Seperti jual beli lainnya, waktu yang bersifat universal memiliki korelasi dan pengaruh terhadap jual beli salam. Hal yang perlu diperhatikan terkait waktu dalam akad salam yaitu:

1. Waktu pembayaran.

Saman atau nilai harga harus dibayarkan muslam (pembeli) kepada muslam 'alaibi pada saat kontrak disepakati. ${ }^{29}$ Penundaan penyerahan pembayaran menyebabkan akad salam bisa batal. Tapi Imam Malik memberi kelonggaran dengan memberikan waktu tambahan tiga hari bagi pembeli untuk melakukan pembayaran. ${ }^{30}$ Hal yang sudah disepakati dalam kontrak tidak dapat diubah selama jangka waktu akad.

2. Waktu penyerahan barang.

Penyerahan barang harus dilakukan di kemudian. ${ }^{31}$ Kedua belah pihak harus sepakat tentang waktu penyerahan muslam fib (barang). Ketiadaan penetapan waktu penyerahan atau ‘ajal majbu $>$ l menyebabkan rusaknya transaksi salam. Jika semua atau sebagian barang tidak tersedia pada waktu penyerahan, atau kualitasnya lebih rendah dan pembeli tidak menerimanya, maka ia memiliki dua pilihan. Pertama,

${ }^{28}$ Muhammad bin Ismail Al-Bukhary. Sabih Al-Bukhary. Juz 3. Cet. 1. (Beirut: Dar Tuq An-Najah, 1422H), hlm. 85.

${ }^{29}$ Siti Mujiantun. Jual Beli Dalam Perspektif Islam: Salam dan Istisna', Jurnal Riset Akutansi dan Bisnis. Vol. 13. No. 2 September 2013. hlm. 209.

${ }^{30} \mathrm{Abu}$ Umar Yusuf Al-Qurtuby. Al-Kafy Fi Fiqh Abl Al-Madinah. Juz 2. Cet. 2. (Riyadh: Maktabah Riyad Al-Hadisah, 1980M), hlm. 692.

${ }^{31}$ Siti Mujiantun. Jurnal Riset. hlm. 209 
Membatalkan kontrak dan meminta kembali uangnya. Kedua, Menunggu sampai barang tersedia. ${ }^{32}$

3. Sifat waktu atau durasi.

Waktu bersifat mengikat bagi muslam 'alaibi. Karena sifatnya mengikat atau lazim maka muslam 'alaibi wajib menyerahkan barang dalam tempo yang sudah disepakati. Penjual dapat menyerahkan barang lebih cepat dari waktu yang disepakati dengan syarat kualitas dan jumlah barang sesuai dengan kesepakatan, dan ia tidak boleh menuntut tambahan harga. ${ }^{33}$

4. Kaitan waktu dan kemungkinan.

Barang yang ditentukan harus mungkin untuk bisa diserahkan dalam tempo yang ditentukan. Bila secara praduga barang tersebut tidak bisa atau mustahil diserahkan dalam waktu yang disepakati seperti membangun rumah berskala besar dalam tempo satu hari setelah akad maka ini bisa menyebabkan rusaknya transaksi salam.

Dapat dipahami bahwa kejelasan durasi merupakan senyawa yang tidak boleh diabaikan dalam akad salam. Pengabaiannya menyebabkan rusaknya akad secara syara'.

\section{Bai' 'iwadain}

Dari hubungan waktu dan jual beli, muncul juga jenis bai' iwsadain, yaitu penyerahan barang dan pembayaran sama-sama tertunda. Jual beli ini juga dikenal dengan bai' al-kali 'bi al-kali, bai' al-dain bi al-dain dan juga bai' al-nasiah bi al-nasiah atau secara bahasa dapat juga diartikan dengan jual beli hutang dengan hutang. Model ini memiliki banyak varietas ataupun turunan, tapi esensinya ada pada penundaan penyerahan barang dan penundaan pembayaran dalam satu akad jual beli yang mengikat. Bila tidak mengikat, maka akad tersebut tidak termasuk akad jual beli.

Transaksi jual beli hutang dengan hutang ini merupakan transaksi yang dilarang sesuai dengan konsesus ulama. ${ }^{34}$ Walaupun hadis larangan jual beli hutang dengan hutang diklasifikasi sebagai hadis lemah, tapi ulama tetap melihat jual beli ini haram. Keharaman ini lebih terfokus pada kemungkinan besar munculnya penipuan, kecurangan dan unsur-unsur negatif lainnya dan minimnya manfaatdari transaksi model ini.

Bentuk jual beli hutang dengan hutang secara prinsip berbeda dengan jual beli hutang secara tunai (bai' al-dain naqdan fi al-bal). Y. Sonafist memasukkan jual beli hutang secara tunai ke dalam jenis jual beli hutang dengan hutang. Jual

32 Siti Mujiantun. Jurnal Riset. hlm. 209

${ }^{33}$ Siti Mujiantun. Jurnal Riset. hlm. 209

${ }^{34}$ Wahbah Al-Zuhaily. Al-Figh Al- 'slamy wa 'Adillatuh. Juz 5. Cet. 4. (Damaskus: Dar Al-Fikr, 2011M), hlm. 3404. 
beli hutang secara tunai lebih kepada pelunasan hutang dengan menggunakan hutang yang ditukarkan dengan sesuatu yang nilainya dilakukan secara konversi. Jual beli hutang secara tunai dibolehkan oleh mayoritas ulama mazhab. ${ }^{35}$

Dari sisi waktu, ada beberapa hal yang perlu diperhatikan, antara lain:

1. Penundaan waktu penyerahan barang dan pembayaran secara bersamaan.

Penundaan waktu penyerahan dan pembayaran secara bersamaan pada akad jual beli adalah terlarang. Hal ini disepakati oleh ulama salaf.

2. Kesepakatan atas durasi waktu.

'Ajal ma'lum atau jelasnya durasi waktu penundaan dan disepakati, baik waktu penyerahan barang dan waktu pembayaran tidak mengubah hukum asal jual beli ini sebagai jual beli terlarang.

3. Resiko penundaan waktu.

Penundaan waktu di kedua belah pihak memunculkan resiko yang lebih besar, baik bagi penjual maupun bagi pembeli. Hal ini dilihat dari aspek perubahan nilai pada barang dan pada uang kartal, belum lagi hal ini dapat menimbulkan praktek riba.

4. Waktu yang singkat.

Menurut Imam Malik, bila pembayaran tertunda maksimal tiga hari maka hal itu boleh. Hal ini di dasari pada aturan islamic legal maxim yaitu kaidah apa yang mendekati sesuatu maka dia dihukumi dengan sesuatu itu. Tiga hari -menurut Imam Malik- masih dihukumi dengan pembayaran di awal karena durasinya yang tidak terlalu jauh. Dalam hal ini keterlambatan pembayaran maksimal tiga hari membuat dia dihukumi dengan akad salam.

\section{Kesimpulan}

Secara global, jual beli termasuk dalam aktifitas mubah selama tidak ada hal-hal yang dapat merusaknya seperti garar, penipuan, kecurangan, paksaan dan lain sebagainya. Pelaku ekonomi dapat memilih metode atau cara bertransaksi sesuai dengan keinginannya. Inovasi dan kreatifitas para pelaku usaha dari masa ke masa menghasilkan sistem jual beli yang dirasa lebih efektif dan efisien, sehingga muncul berbagai jenis jual beli yang berkembang di masyarakat. Jual beli sebagai salah satu pengerak ekonomi masyarakat mempunyai berbagai jenis dan pembagian. Salah satu pembagiannya adalah jual beli berdasarkan waktu. Dari pembagian jual beli berdasarkan waktu, muncul 4 model jual beli yaitu, jual beli tunai, jual beli dengan pembayaran yang tertunda, jual beli dengan penundaan penyerahan barang, dan jual beli dengan penundaan penyerahan barang dan pembayaran. Dari keempat model ini, hanya jual beli hutang dengan hutang yang dilarang dalam syariah. Hasil analisa menunjukkan bahwa setiap

${ }^{35}$ Y. Sonafist. Utang Piutang Dalam Perspektif Fiqh. Jurnal Islamika. Vol. 15. No. 1. 2015, hlm. 117. 
model ini memiliki keterikatan terhadap waktu. Pengabaian atas waktu, periode dan durasi pada suatu akad, baik pada sisi pembayaran maupun penyerahan barang dapat penyebabkan tidak sahnya transaksi tersebut dalam kacamata syara'.

\section{Daftar Pustaka}

Abidin, Muhammad Amin Ibnu. Radd Al-Mukbtar 'Ala Al-Darri Al-Mukbtar. Juz 4. Beirut: Dar Al-Fikr, 1992.

Adam, Panji. Fikih Muamalah Maliyah. Bandung: Refika Aditama, 2017.

Al-Bukhary, Muhammad bin Ismail. Sabih Al-Bukbary. Juz 3. Beirut: Dar Tuq An-Najah, $1422 \mathrm{H}$.

Al-Dasuqi, Muhammad bin Ahmad. Hasyizah Al-Dasuqi Ala Syarh Al-Kabir. Jilid 3. Beirut: Dar Al-Fikr, tt.

Al-Dimasyqi, Taqiyuddin. Kifayah Al-Akhyar fi Halli Gayah Al-Tkbtisar. Kairo: Dar Al-Salam, 2007.

Al-Dimyathi, Abu Bakar. 'T'anah Al-Talibin. Juz 3. Beirut: Dar Al-Fikr, 1997 M.

Al-Fakihi, Abu Abdullah. 'Akbar Al-Makkah fi Qadim Al-Dabri wa Hadisih. Juz 3. Beirut: Dar Khad\}ar, 1414 H..

Al-Janzany, Syiahabuddin. Takhrij Al-Furu' 'Ala Al-Usul. Beirut: Muassasah AlRisalah, $1398 \mathrm{H}$.

Al-Maghriby, Al-Husein bin Muhammad. Al-Badr Al-Tamam Syarh Bulug AlMuram. Juz 6. Kairo: Dar Hajar, 2007.

Al-Nawawi, Abu Zakaria. Al-Majmu' Syarh Al-Muhazzab. Juz 9. Beirut: Dar AlFikr, 1996.

Al-Qurtuby, Abu Umar Yusuf. Al-Kafy Fi Figh Abl Al-Madinah. Juz 2. Riyadh: Maktabah Riyad Al-Hadisah, 1980.

Al-Syarbaini, Muhammad Syamsuddin. Al-'IqnäfiHalli Alfar̨i Abi Syuja'. Juz 2. Beirut: Dar Al-Kutub Al-'Tlmiyah, 2004.

Al-Syaukani, Muhammad bin Ali bin Muhammad. Nail Al-Autar min 'Ahadisi Sayyid Al- Akbyar. Juz 5. Beirut: Dar Jail, 1973.

Al-Yassu'i, Louis Ma'luf. Al-Munjid fi Al-Lugah wa Al- A'lam. Beirut: Dar AlMasyriq, 1986.

Al-Zuhaily, Wahbah. Al-Fiqh Al-'Islamy wa 'Adillatuh. Juz 5. Damaskus: Dar AlFikr, 2011.

Hanbal, Imam Ahmad bin. Musnad Imam Ahmad bin Hanbal. Juz 12. Beirut: Muassasah Al-Risalah, 2001. 
Hibban, Muhammad bin. Sabib Ibn Hibban. Juz 1. Beirut: Muassasah Al-Risalah, 1993.

Hidayah, H. Hasbudin Wa Ode Nur. Pengarub Uang Muka dan lama Angsuran Terhadap Volume Penjualan Motor Yamaba Pada CV. Citra Selaras Raba. UHO: Jurnal Akuntansi dan Keuangan Fakultas Ekonomi Dan Bisnis. Vol. 1. No. 1. 2016.

Malik, Malik bin Anas bin. Muwatta' Imam Malik. Juz 2. Beirut: Muassasah AlRisalah, $1412 \mathrm{H}$. . Muwatta Imam Malik. Juz 4. Abu Dhabi: Muassasah Zayid bin Sultan, 2004.

Mandzur,Muhammad bin Makram bin. Lisan Al-Arab. Juz 8. Beirut: Dar AlSadir, 1414 H.

Muslim, bin Hajjaj Al-Nisabury. Sahih Muslim. Juz 4. Beirut: Dar `Ihya`AlTuras Al-'Araby, tt.

Mujiantun, Siti. Jual Beli Dalam Perspektif Islam: Salam dan Istisna'. Jurnal Riset Akutansi dan Bisnis. Vol. 13. No. 2 September 2013.

M.S. Syaifullah. Etika Jual Beli Dalam Islam. Hunafa: Jurnal Studia Islamika. Vol. 11. No. 2. Desember 2014.

Muchlis, Ridwan. Analisis SWOT Financial Technology (Fintech) Pembiayaan Perbankan Syariah Di Indonesia; Studi Kasus 4 Bank Syariah Di Kota Medan. At-Tawassuth. Vol. III. No. 2. 2018.

Nujaim, Zainuddin bin Al-Mashry Al-Hanafi. Al-Bahr Al-Ra iq Syarb Kanz, AlDaqa iq. Juz 5. Kairo: Dar Al-Kitab Al-`Islamy, tt.

Nasution, Adanan Murroh. Jual Beli Kredit Ditinjau Dari Persefektif Hukum Islam. Yurisprudentia. Vol. 2 No. 2 Desember 2016.

Saprida. Akad Salam dalam Transaksi Jual Beli. Mizan. Vol. 4. No.1. 2016.

Sonafist, Y. Utang Piutang Dalam Perspektif Fiqh. Jurnal Islamika. Vol. 15. No. 1. 2015. 
142 | Al-Istinbath: Jurnal Hukum Islam, Vol.4, No.1, 2019

HALAMAN SENGAJA DIKOSONGKAN 